\title{
Best practices for the rational use of water in construction sites in Brazil
}

\author{
Ludimilla de Oliveira Zeule ${ }^{1}$ | Sheyla Mara Baptista Serra ${ }^{2}$ () | \\ José Manuel Cardoso Teixeira ${ }^{3}$
}

\author{
${ }^{1}$ Doctor in Civil Construction, Civil \\ Engineering Postgraduate Program, Federal \\ University of São Carlos (UFSCar), São Carlos, \\ São Paulo, Brazil \\ ${ }^{2}$ Associate Professor, Civil Engineering \\ Postgraduate Program, Civil Engineering \\ Department, Federal University of São Carlos \\ (UFSCar), São Carlos, São Paulo, Brazil \\ ${ }^{3}$ Associate Professor, School of Engineering, \\ Civil Engineering Department, University of \\ Minho, Guimarães, Portugal

\section{Correspondence} \\ Sheyla Mara Baptista Serra, Associate Profes- \\ sor, Civil Engineering Postgraduate Program, \\ Civil Engineering Department, Federal Uni- \\ versity of São Carlos (UFSCar), São Carlos, São \\ Paulo, Brazil. \\ Email:sheylabs@ufscar.br \\ Funding information \\ Coordenação de Aperfeiçoamento de Pes- \\ soal de Nível Superior, Grant/Award Num- \\ ber: Finance Code 001; Financiadora de \\ Estudos e Projetos, Grant/Award Number: \\ 01.11.0056.00
}

\begin{abstract}
Even though water is a scarce resource, not much thought has been given to its proper use during the execution phase of the building, unless this construction site has already acquired sustainability criteria or certification program. The purpose of this study is to assess the sustainability practice of the rational use of water and its application in the execution phase of construction sites in Brazil. The research proposes a list of items that facilitates the implementation of sustainability in construction sites by creating a checklist of sustainable practices based on environmental certification programs. This article uses the case study by a qualitative method, which can evaluate the major difficulties and the best occurrences of sustainable practices related to water use in construction sites. This work consists of six projects of various typologies and geographical locations in Brazil. The adoption of this list may serve as a tool for the implementation of sustainability in construction sites and as a benchmark among the companies. Finally, best practices for the rational use of water are proposed at the construction sites.

KEYWORDS

civil construction, construction site, environmental management, sustainability, water reuse, water
\end{abstract}

\section{1 | INTRODUCTION}

Water is a resource finite and necessary for the balance of human life and most economic activities (UNESCO, 2020; Usman \& Abdullah, 2018; Waidyasekara, De Silva, \& Raufdeen, 2013). Zutshi and Creed (2015) agree that individuals and organizations require a built environment for the full range of social and industrial activities, but the natural environment must support and sustain the built environment. For Castro, Loureiro, Santos, Silva, and Rauen (2017), water management approaches are required to promote a rational use of resources, but the effectiveness of actions in promoting sustainability also depends on factors that are not under the direct competence of water managers. Aspects such as education, income, health, and level of environmental awareness of a population all interact to determine the form and intensity of water use. For Waidyasekara et al. (2013), many construction activities use potable water during the construction process and could be a mere wastage and misuse of water. Other waste of water can be water pollution and environmental damage.

The construction industry, usually known for consuming a lot of natural resources, has considerable influence over the management of the environment and somehow triggered the adoption of sustainable postures by their agents (Ahn, Shin, Jeon, \& Jung, 2017). Thus, different sustainable practices in the production cycle of construction and the pursuit of certification in various enterprises were found, seeking to register the innovations to the society and as a way for the companies to remain competitive in the market. Currently, there are several certifications of sustainability for buildings, originated in different parts of the world, available to entrepreneurs and society. 


\section{The construction industry, usually known for consuming a lot of natural resources, has considerable influence over the management of the environment and somehow triggered the adoption of sustainable postures by their agents}

Certification programs operate as a quality parameter incorporated into the building. According to the United States Green Building Council (USGBC, 2019), Brazil is the fourth country in the world ranking of green buildings, with 531 buildings in certification process Leadership in Energy and Environmental Design (LEED). For the USGBC, the development of the sustainable construction industry involves the adoption of best practices and an integrated process of design, construction, and operation of buildings and built spaces.

The implementation of the sustainable certification program brings environmental, economic, and social benefits and the buildings taking the "green criteria" into account profit from the reduction of operational costs, improve the safety and health of workers and occupants, the rational use of natural resources, among other advantages (Halliday, 2010).

According to Thomson and El-Haram (2014), currently, sustainability assessment practice has largely failed to achieve integration between the phases of a project. For these authors, a holistic approach to sustainability should be promoted, aiming to be understandable, managed, and aligned with available sustainability assessment methods. Among the principles to be followed are the use of local and sustainable materials, as well as the rational use of water and energy.

Several practices that help to reduce the impacts need to be better known: water usage, water use reduction, water monitoring, use of efficient fittings, and use of graywater and rainwater. Sustainable practices must be adopted in construction sites to save water, which is used in large quantities in the living areas and the process of production of concrete and mortars, in the painting, cleaning, and so on (Al-Qawasmi, Asif, El Fattah, \& Babsail, 2019).

So, this article focused on presenting guidelines and solutions found in the references and case studies for the rational use of water in construction sites, and it is based on the original research by Zeule (2014).

\section{2 | RECOMMENDATIONS FOR REUSE OF WATER}

There are several types of research and guidelines for the use of strategies to minimize and control the consumption the water within the construction sites. However, there is no massive deployment, perhaps due to the lack of inspection or standardization state and national. One of the most recommended practices is the reuse of water.

The well-known and consulted international manual for water reuse is the "Guidelines for Water Reuse" published jointly by the US Environmental Protection Agency (EPA) and the Agency for International Development in 2004 and reissued in 2012. The manual has as its main objective to guide the reuse of water in places where there are no rules for such practice (EPA, 2012).

The Department of Employment and Industrial Relations (Queensland Government, 2007) has proposed a specific document for the construction industry, "Model Water Management Plan for the Queensland Civil Construction Industry," which is intended to help manage water-related health and environmental risks associated with civil construction work activities, which include manufacturing, supplying, storing or using recycled water such as that supplied from a municipal sewage treatment plant; or supplying or using water from sources such as creeks, dams, and stormwater. This document also indicates the types of control measures that can be implemented to allow the recycled water provider to supply, and the user to make use of, a lesser quality of recycled water.

Brazil has several regulatory documents, such as Brazilian Standards (Norma Brasileira) NBR 15.527 of the Brazilian Association of Technical Standards (Associação Brasileira de Normas Técnicas; ABNT, 2007), which deals with the exploitations of rainwater for its reuse; the Resolution number 357 of the National Environmental Council (Conselho Nacional do Meio Ambiente; CONAMA, Brasil, 2005), which classifies water according to the quality required for their predominant uses in 13 classes (among them, water for human consumption); the National Water Resources Policy (Brasil, 1997); and NBR 13.969 (ABNT, 1997), which is not specific for reuse but has an item defining classes of water reuse and an indication of expected quality standards, which describes the units of posttreatment and suggests alternatives for the final disposal of liquid effluents from septic tanks.

There are also several recommendations and rules of the National Health Surveillance Agency (Agência Nacional de Vigilância SanitáriaANVISA), which is responsible for overseeing aspects of people's health in Brazil. According to Ministério da Saúde, Brasil (2011), all the water intended for human consumption, collectively distributed through a collective alternative water supply system or solution, should be subjected to control and supervision of water quality. To check the water quality, parameters of international reference should be followed, for instance, the methodologies proposed by the World Health Organization (WHO), among others.

For the Environmental Company of the State of São Paulo (Companhia Ambiental do Estado de São Paulo; CETESB, 2020), the water reuse is part of a broader activity, which is the rational and efficient use of water, also including the control of loss and waste of the production and consumption of water.

For Giacchini (2016), it is possible to use graywater (or greywater) and rainwater reuse strategies. The graywater comes from the showers, washbasins, bathtubs, tanks, and washing machines. It is important to observe if the water collected (rainwater and/or graywater) is 
properly treated for later reuse and whether the devices for collecting rainwater are separated from drinking water facilities to prevent contamination of drinking water. However, even for non-potable uses, sanitary quality must be guaranteed through proper treatment. The processes used to treat graywater are like those used in sewage treatment plants (Giacchini, 2016).

An experimental study by Santos, Taveira-Pinto, Cheng, and Leite (2011) includes the analysis of the efficiency of treatment and the assessment of the quality potential of treated graywater, with low cost and easy maintenance for the reuse, being the gross graywater collected from sinks/lavatories public water and water from locker room showers. The system showed potential for recovery of graywater, but concentrations of some solids were not low enough to reach the limits presented in legal and reference documents.

Thus, alternatives to water reuse are highlighted because it is a finite natural resource and deserves great attention for its proper use and reuse. The stage of construction site consumes large amounts of water, but most activities do not need to use drinkable water, so, it is possible to direct the reuse water for activities such as spraying water at the construction site, vehicle wheel wash, and washing equipment.

\section{3 | THE CONTEXT OF CONSTRUCTION SITES}

Typical water sources for construction include natural water bodies, potable water supply pipes, artesian wells, water trucks, non-potable water from rainwater, reused wastewater treatment plants, and recycled water (where water from one process is later used in another process; Borja, César, Cunha, \& Kiperstok, 2018; Thornback, Snowdon, Anderson, \& Foster, 2015).

According to Waidyasekara et al. (2013), many construction activities use potable water during the construction process, and the consumption of potable water used by the construction industry is difficult to determine. For Santos, Silva, and Cerqueira (2015), the water waste can occur due to negligence on the part of users, precarious hydraulic and sanitary installations, inadequate project design, leaks, flaws in or lack of maintenance. Water pollution and environmental damage due to construction work are other negative impacts.

For Waylen and Williams (2011), key water using processes on construction sites are:

- Site cabins and temporary accommodation;

- General site activities including tool washing;

- Wet trades, such as brickwork, screeding, concreting, and plastering;

- Groundworks, including grouting and drilling;

- Dust suppression, including road and wheel washing;

- Hydro demolition;

- Cleaning of tools and plant equipment, lorry washing;

- Commissioning and testing of building plant and services.

According to the Regulatory Standard 18, which describes the "Work Conditions and Environment in the Construction Industry"
EXHIBIT 1 Distribution of water consumption in the construction site

\begin{tabular}{lll} 
Stage/factor & Consumption $\left(\mathrm{m}^{3}\right)$ & Percent \\
\hline Foundation & 6.69 & 0.11 \\
\hline Structure & 418.19 & 6.77 \\
\hline Masonry & 14.86 & 0.24 \\
\hline Coating & 123.58 & 2.00 \\
\hline Waterproofing (tests) & 480.74 & 7.79 \\
\hline Human use & $3,575.60$ & 57.90 \\
\hline Others & $1,555.34$ & 25.19 \\
\hline Total & $6,175.00$ & 100.00 \\
\hline
\end{tabular}

From: Santos et al. (2015).

(BRASIL, 2018), the use of water in construction sites is related to the essential demands of the employees and must be present in the basic items: (a) refectory, (b) sanitary facilities, and (c) drinking fountains. In general, water should also be present in the work fronts to meet the demands of activities and services.

The construction of temporary facilities is essential for the beginning of activities in a construction site, so it must have a specific design, specifically studied before it is carried out. The design should consider the forecast of water consumption for human use and the productive activities, the choice of supply and feeding conception model, the physical implementation of the system, and the maintenance of the water facilities in the building.

Santos et al. (2015) investigated the consumption of water in different services of a construction site in the city of Recife, Brazil, during the period from January 2011 to December 2013. The building was reinforced concrete and the results are shown in Exhibit 1. The "Others" factor includes water waste, human consumption in the cafeteria and kitchen, indirect uses such as cleaning, tests to check hydraulic, sanitary and rainwater pipes, and spraying water on the floor to reduce dust. The indicator of water volume by built area, according to these authors, was $0.83 \mathrm{~m}^{3} / \mathrm{m}^{2}$, considering the construction area of $7,467.66 \mathrm{~m}^{2}$ and the total water consumption of $6,175.00 \mathrm{~m}^{3}$. If only human consumption is considered $\left(3,575.60 \mathrm{~m}^{3}\right)$, the indicator of water volume by the built area was $0.48 \mathrm{~m}^{3} / \mathrm{m}^{2}$

To determine the water consumption indicators, the calculation method to be followed must be previously defined. The form of water supply also impacts likely losses.

There are several possibilities for water supply at construction sites: the existing public network of water supply, water abstracted from groundwater, or water abstracted from surface water by delivery by water tanker vehicles. According to Reis, Souza, and Oliveira (2004), the design of hydraulic systems in construction sites helps to minimize excessive consumption of water, helping to reduce the environmental impact of construction. Depending on the possibility implemented, there is a wide variety of concepts of hydraulic layouts that can be adopted as solutions for the water distribution inside the construction site. Exhibits 2 and 3 show water supply situations at the construction sites. 


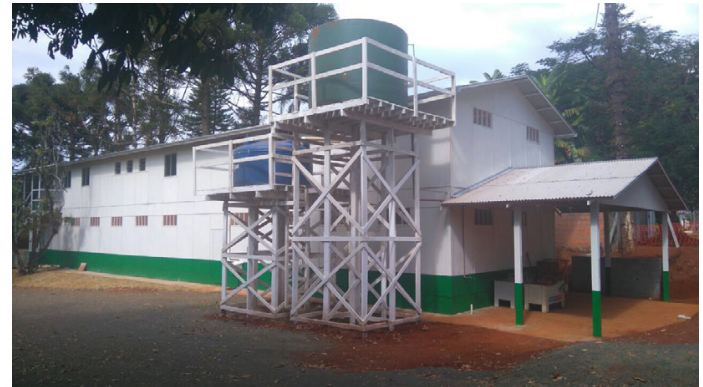

EXHIBIT 2 Use of elevated temporary reservoirs connected to the public water network [Color figure can be viewed at wileyonlinelibrary.com]

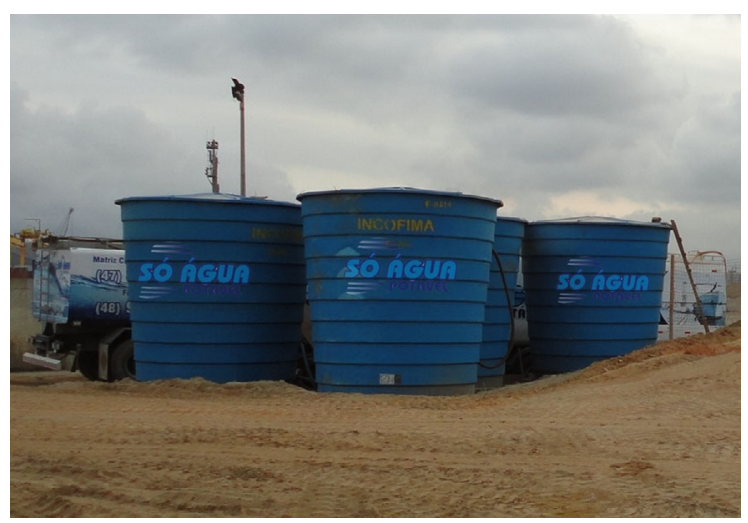

EXHIBIT 3 Use of temporary reservoirs supplied by the water truck. From: http://www.soaguapotavel.com/ [Color figure can be viewed at wileyonlinelibrary.com]

Reis et al. (2004) state that the option for the implementation of a direct water supply system from the public network may be considered advantageous at the first moment due to the need for lower investments to implement the provisional facilities of water in the construction sites. However, the high pressure of water coming from the public network may cause a greater consumption in some places and generating the more damage to the connections of power extensions such as breaks connections, leaks, Ariete scams, among others.

Besides that, Reis et al. (2004) claim that the use of water reservoirs enable a safe functioning and more rationalized consumption once there is not a continuous supply of water by the dealers, and also because of the greater possibility of pressure control to which extensions feeds are submitted.

The depletion of the water served in the construction site by the public system, when poorly done, can cause leaks and hence percolation of sewage through the soil, contaminating surface and groundwater. Thus, another practice to be cited is the use of "technologies for wastewater," which may consider the quality of sewer facilities in the construction site, the method used to collect wastewater (sewage), the possible existence of reservoir for sedimentation of waters with particulate material, such as hardened mortar, plaster, and other debris that could interfere in the sewage collection system. The occurrence of periodic maintenance of such facilities should also be evaluated.

Another best practice evaluated is the "reduced consumption," where it can be checked if the site has activities to instruct employees on how to generate water savings, and if they put them into practice. For the effectiveness of this strategy, it is also important to mention the use of equipment to reduce water consumption. Some manufacturers of sanitary equipment make available on the market the taps with a proximity sensor and toilets with dual drive flush for liquids and solids.

Therefore, it would be a good option to use water-saving equipment (toilet with attached box, discharge with double intensity for activation of flow, drive faucets with sensor taps with timer, aerate valve taps) also during the execution phase.

The water forecast for human consumption and productive activities in the construction site must be carried out, adopting a sourcing and supply model following the conditions of the region. The knowledge and adoption of good practice for the use of water can ensure a continuous supply in adequate quantity and quality, with

EXHIBIT 4 Parts of the checklist of the LEED for new construction and major renovation

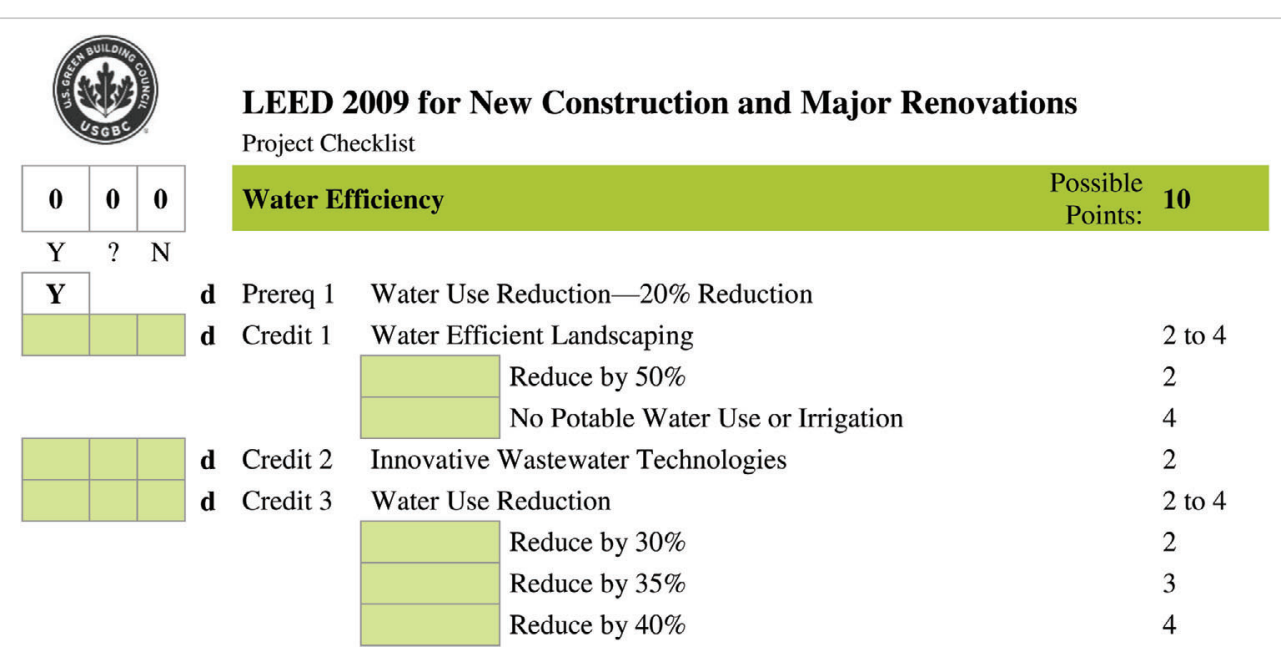

From: USGBC (2009). 
EXHIBIT 5 Reference sources and subsequent questions from the survey instrument developed

\begin{tabular}{|c|c|c|c|c|}
\hline $\begin{array}{l}\text { LEED (U.S. Green } \\
\text { Building Council, } \\
\text { 2009) }\end{array}$ & AQUA-HQE (FCAV, 2013) & $\begin{array}{l}\text { BREEAM (BRE, } \\
\text { 2009) }\end{array}$ & $\begin{array}{l}\text { Blue House Seal (CEF, } \\
\text { 2010) }\end{array}$ & Checklist question \\
\hline \multicolumn{5}{|c|}{ Rainwater and graywater harvesting } \\
\hline $\begin{array}{l}\text { Project for } \\
\text { rainwater } \\
\text { controlling the } \\
\text { quantity and } \\
\text { quality }\end{array}$ & $\begin{array}{l}\text { The project of rainwater for } \\
\text { discharge/treatment and } \\
\text { waterproofing. The collection } \\
\text { devices must be completely } \\
\text { separated from potable water } \\
\text { tanks }\end{array}$ & $\begin{array}{l}\text { Rainwater project } \\
\text { water }\end{array}$ & $\begin{array}{l}\text { Rainwater retention and } \\
\text { reuse }\end{array}$ & $\begin{array}{l}\text { 1. Is there or will there be any } \\
\text { system for rainwater harvesting? } \\
\text { 2. Is there or will there be any } \\
\text { system for graywater harvesting? } \\
\text { 3. Is the water collected (rain } \\
\text { and/or graywater) properly } \\
\text { treated for reuse? } \\
\text { 4. Are the rainwater collection } \\
\text { devices separated from the } \\
\text { potable water? }\end{array}$ \\
\hline
\end{tabular}

\section{Technologies for wastewater}

\begin{tabular}{|c|c|c|c|c|}
\hline $\begin{array}{l}\text { Efficiency in the } \\
\text { use of water } \\
\text { and innovative } \\
\text { technologies } \\
\text { for wastewater } \\
\text { treatment }\end{array}$ & $\begin{array}{l}\text { Sanitary quality of water. } \\
\text { Maintenance of facilities }\end{array}$ & $\begin{array}{l}\text { Ensuring the } \\
\text { quality of } \\
\text { sanitary water. } \\
\text { Detecting and } \\
\text { preventing } \\
\text { water leakage }\end{array}$ & $\begin{array}{l}\text { The minimum radius of } \\
2.5 \mathrm{~km} \text { away from } \\
\text { sewage treatment } \\
\text { plants (WWTP) }\end{array}$ & $\begin{array}{l}\text { 5. Was planned a discharge } \\
\text { wastewater system during the } \\
\text { building design? } \\
\text { 6. Are the wastewater facilities } \\
\text { periodically checked? }\end{array}$ \\
\hline \multicolumn{5}{|c|}{ Reduced consumption } \\
\hline $\begin{array}{l}\text { Reduction of } \\
\text { consumption }\end{array}$ & $\begin{array}{l}\text { Potable water reduction and control. } \\
\text { Toilet flushing tank with a capacity } \\
\text { smaller than or equal to } 6 \text { liters }\end{array}$ & $\begin{array}{l}\text { Water } \\
\text { consumption } \\
\text { monitoring }\end{array}$ & $\begin{array}{l}\text { Individual measurement } \\
\text { of water. } \\
\text { Water-saving disposals: } \\
\text { flushing systems, } \\
\text { meters, aerators, flow } \\
\text { reducers }\end{array}$ & $\begin{array}{l}\text { 7. Is there awareness from the } \\
\text { workers for the reduction of } \\
\text { water consumption? } \\
\text { 8. Are there any measures taken to } \\
\text { fight the water waste? } \\
\text { 9. Do the bathrooms have } \\
\text { equipment that saves water? }\end{array}$ \\
\hline
\end{tabular}

From: Adaptation from Zeule (2014).

enough pressure, providing good conditions to meet the needs from demand, energy consumption reduction, and rationing in the form of use.

\section{4 | RESEARCH METHOD}

In the methodological field, this research is classified as a descriptive study of multiple cases because, according to Yin (2013), this work has a contemporary focus, whose data obtained are from more than one case and intends to answer the main research question with structuring like "How?" and "Why?." The proposed research is qualitative, not aimed at making quantitative measurements at the construction site.

The research initially sought a comparison of guidelines and scoring rules for the environmental certification programs to develop a single instrument for the observation of sustainability in construction sites (Zeule, Serra, \& Teixeira, 2019). Thus, a comparative table was made based on the four certifications seals in Brazil:

- LEED for New Construction and Major Renovation (USGBC, 2009);

- Building Research Establishment Environmental Assessment Method-BREEAM (BRE, 2009);
- AQUA-HQE process, based on the French label HQE (Haute Qualité Environnementale) by Foundation Carlos Alberto Vanzolini (FCAV) (FCAV, 2013), and

- Blue House Seal from the Federal Savings Bank (Caixa Econômica Federal) (CEF, 2010).

Exhibit 4 shows the parts of the original checklist of the LEED seal that served this research, where the three main questions for the rational use water can be verified: water-efficient landscaping, innovative wastewater technologies, and water use reduction.

Thus, the documents of the other three certifications seals were consulted to assemble a unique evaluation checklist. The six-topic checklist developed is (1) sustainable site, (2) rational use of water, (3) rational use of energy, (4) materials and resources, (5) environmental quality, and (6) innovations and processes, based in the LEED structure (Zeule et al., 2019). Exhibit 5 presents the issues that must serve as a guide to verify the sustainability in a construction site, only concerning the item "(2) rational use of water." The last column corresponds to the classification and questions adopted in the checklist proposed, on which this search is based.

The checklist items to be applied in the analysis of best practices for the rational use of water can be seen in Exhibit 6. The researcher, checking the situation at the construction site, indicates one of the five 
EXHIBIT 6 Options of checklist for the "rational use of water"

\subsection{Rain and graywater harvesting}

2.1.1 Is there or will there be any rainwater collection system?

$0=$ Not predicted

$1=$ Yes, only for the occupation phase, with treatment

$2=$ Yes, collection at the construction site in reservoirs, without treatment

$3=$ Yes, on the construction site, with treatment

$4=$ Yes, on construction site and occupation, with treatment

$\mathrm{NA}=$ From the beginning of the work to the present moment, it is not the right time to collect rainwater (lack of precipitation). Favorable collection NE Brazil: February to May; favorable collection SE Brazil: November to March

2.1.2 Is there or will there be any wastewater collection system?

$0=$ Does not have

$1=$ In implantation

$2=$ Yes, the occupancy phase only

$3=$ Yes, only at the construction site

$4=$ Yes, at the construction site and occupation phase

2.1.3 Is the collected water (rain and/or graywater) correctly treated for reuse?

$0=$ Are not captured or captured and are not treated

$1=$ Not because it only uses rainwater for gardening and uses that do not need treatment

$2=$ Yes, treatment with adapted technology (has no design and technical responsible)

$3=$ Yes, treatment with technologies by filter systems

$4=$ Yes, treatment with commercial equipment

2.1.4 Are the rainwater collecting devices separated from the potable water tanks?

$0=$ Are not separated

$4=$ Yes, are separated

\subsection{Technologies for wastewater}

2.2.1 Was a discharge wastewater system planned during building design?

$0=$ None

$1=$ Yes, by temporary pipes

$2=$ Yes, only chemical toilet with periodic collection

$3=$ Yes, by septic tank

$4=$ Yes, by definitive public network

2.2.2 Are the wastewater facilities periodically checked?
$0=$ No
$1=$ Only when it clogs
$2=$ Every two months or more
$3=$ Monthly
$4=$ Weekly

\subsection{Decrease in consumption}

2.3.1 Is there awareness from the workers for the reduction of water consumption?

$0=$ No

$1=$ There was a lecture for a few construction workers

$2=$ There was a lecture for most construction workers

$3=$ Yes, there was a lecture for all workers

$4=$ Yes, with frequent lectures and signposts
EXHIBIT 6 (Continued)

2.3.2 Are there any measures taken to fight the water waste?

\section{Actions implemented}

() technological actions (such as consumption-reducing equipment),

( ) social actions (such as worker awareness), ( ) economic actions

(allocation of financial resources to previous actions), and ( ) others

Option A. ( ) public network supply system

$0=$ No financial resources are allocated for the

implementation of control measures

$1=$ Construction site with direct connection

$2=$ Construction site with an indirect or mixed connection

$3=$ Construction site with a direct connection, together with technological, social, and economic actions

$4=$ Construction site with indirect or mixed connection, together with technological, social, and economic actions

Option B. ( ) system without public network supply

$0=$ No financial resources are allocated for the implementation of control measures

$1=$ Construction site without quality control

$2=$ Construction site with quality control, but without consumption measurement control

$3=$ Construction site with quality and consumption control

$4=$ Construction site with quality and consumption control, together with technological, social, and economic actions

Option C. ( ) mixed supply system

$0=$ No financial resources are allocated for the implementation of control measures

$1=$ Construction site with a clandestine public network connection and without quality control of collected water

$2=$ Construction site with any connection and without quality control of the collected water

$3=$ Construction site with any connection and with quality control of the collected water

$4=$ Construction site with any connection, with quality control of the collected water, together with technological, social, and economic actions

2.3.3 Do the bathrooms have ceramics and metals that save water?

Such as ( ) toilet bowl with coupled box, ( ) flush with double flow intensity activation, ( ) sensor-operated taps, ( ) timer tap, () rope-driven single flush box, ( ) aeration valve on taps, ( ) others

$0=$ No

$1=$ Occupancy phase only or an item on the construction site

$2=$ Two items were observed at the construction site

$3=$ Three items were observed at the construction site

$4=$ Four or more items were observed at the construction site

From: Adaptation from Zeule (2014).

degrees of variation was used, from 0 to 4 . The possible answers to each question were distributed to conform to a Likert scale, which considers a response range with an odd number of options. The highest degree of response in the evaluation, 4 , corresponds to positive sustainability, and the lowest degree, 0 , corresponds to a lack of good practice. The possibility to mark "not applicable" (NA) was also available for studies at construction sites that do not present definitive conditions, excluding this item from the scoring.

At the end of checklist completion, the indicator for the final classification of the site is obtained (Zeule et al., 2019). According to Zeule 
EXHIBIT 7 Proposal for classification of the sustainability level of the construction site

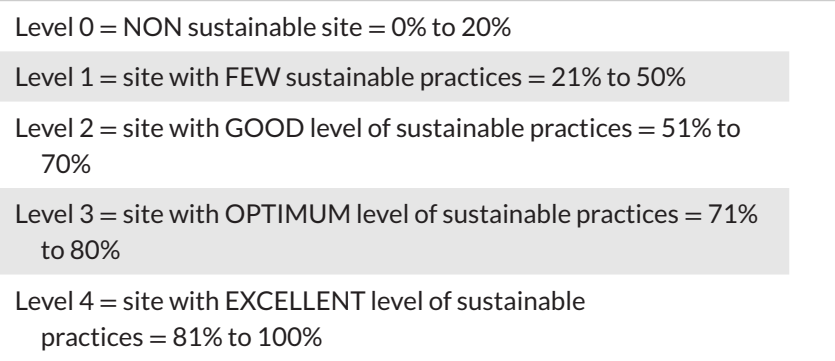

From: Zeule (2014).

(2014), five levels of classification are proposed, organized according to the best practices implemented, as shown in the table in Exhibit 7. The proposal is based on the LEED seal, which has four levels of certification: certified (the simplest), silver, gold, and platinum.

\section{5 | CASE STUDIES}

The projects presented in this article are six. The phase of the sites studied was restricted, identifying sites that were in precast concrete, structure, and/or masonry closing phase to maintain a data collection standard. Exhibit 8 presents the main features of each site visited, identifying whether it is public or private. The research had a qualitative approach to applying the proposed checklist.

With the checklist developed by Zeule (2014), visits were made to the six construction sites identified in Exhibit 8, and situations related to each of the items on the list were recorded. This article presents the study on the rational use of water.

Several sustainable practices were identified in these works, some of which related to the rational use of water. In Exhibit 9 we can observe that sites $A$ and $C$ have an adequate water filtration system, storage, and cooling for consumption by workers at the construction site.

In Exhibit 10 we can observe that site B uses a high-level flushing tank in the workers' restrooms, which has controlled flow for toilets flush, avoiding waste. In Exhibit 11, instructions are shown to workers to save water and care for health and safety next to the washbasins in site D.

We verified some practices used for water reuse, mainly in site $\mathrm{E}$. Exhibit 12 shows the system for capturing rainwater through gutters on the roofs of the temporary installations at the construction site. The water is channeled separately to the rainwater storage and treatment tanks as shown in Exhibit 13.

Exhibits 14 and 15 show the simple rainwater collecting in tube or water bucket without treatment for non-drinkable use (airconditioning and roof).

The site visited uses two other practices, which are the spraying of water on the soil by a rainwater tanker vehicle to prevent dust to go up (Exhibit 16) and the faucet with reuse water for washing vehicle wheels and concrete mixer truck with the metal hose can be seen in Exhibit 17.

\section{6 | RESULTS AND DISCUSSIONS}

Exhibit 18 shows an evaluation of the sustainable practices for the rational use of water observed in each construction site.

Sites A, B, E, and F were supplied by the public network supply system. Sites $C$ and $D$ are in regions far from the urban center. Site $C$ was supplied with water from a river that passed inside the construction site, collected with a water truck, and transferred to tanks. Site D was also supplied with a water truck but with potable water from the distribution service.

In all construction sites, social actions were implemented, such as lectures for workers and technology actions to reduce water consumption. The lectures spoke about the importance of saving water and creating strategies to disseminate this action. Only at site E economic

EXHIBIT 8 Basic characteristics of the construction sites in Brazil

\begin{tabular}{|c|c|c|c|c|c|c|c|}
\hline $\begin{array}{l}\text { Nomen } \\
\text { clature }\end{array}$ & $\begin{array}{l}\text { Constructive } \\
\text { system }\end{array}$ & City and state & Certifications & $\begin{array}{l}\text { Type of } \\
\text { project }\end{array}$ & $\begin{array}{l}\text { Date of } \\
\text { execution }\end{array}$ & $\begin{array}{l}\text { Building area } \\
\left(\mathrm{m}^{2}\right)\end{array}$ & $\begin{array}{l}\text { Dimension } \\
\text { ground }\left(\mathrm{m}^{2}\right)\end{array}$ \\
\hline Site A & $\begin{array}{l}\text { Structural } \\
\text { masonry }\end{array}$ & Fortaleza-CE (NE) & ISO 9001 & Public & $\begin{array}{l}\text { Dec. } 2012 \text { to } \\
\text { Jun. } 2015\end{array}$ & $15,829.81$ & $7,766.07$ \\
\hline Site B & $\begin{array}{l}\text { Structural } \\
\text { masonry }\end{array}$ & $\begin{array}{l}\text { Pindamonhangaba-SP } \\
\text { (SE) }\end{array}$ & $\begin{array}{l}\text { ISO } 9001 \\
\text { ISO } 14001 \\
\text { AQUA-HQE }\end{array}$ & Private & $\begin{array}{l}\text { Dec. } 2011 \text { to } \\
\text { Dec. } 2014\end{array}$ & $19,000.00$ & $35,611.00$ \\
\hline Site C & $\begin{array}{l}\text { Precast } \\
\text { concrete }\end{array}$ & Fortaleza-CE (NE) & ISO 9001 & Public & $\begin{array}{l}\text { Dec. } 2012 \text { to } \\
\text { Dec. } 2014\end{array}$ & $276,800.00$ & $770,000.00$ \\
\hline Site D & $\begin{array}{l}\text { Precast } \\
\text { concrete }\end{array}$ & $\begin{array}{l}\text { São Gonçalo do } \\
\text { Amarante-CE (NE) }\end{array}$ & ISO 9001 & Public & $\begin{array}{l}\text { Mar. } 2013 \text { to } \\
\text { Mar. } 2015\end{array}$ & $24,950.00$ & $120,979.00$ \\
\hline Site $\mathrm{E}$ & $\begin{array}{r}\text { Reinforced } \\
\text { concrete }\end{array}$ & Limeira-SP (SE) & $\begin{array}{l}\text { ISO } 9001 \\
\text { AQUA-HQE }\end{array}$ & Private & $\begin{array}{l}\text { Apr. } 2013 \text { to } \\
\text { Jul. } 2016\end{array}$ & $49,152.01$ & $50,559.00$ \\
\hline Site F & $\begin{array}{r}\text { Reinforced } \\
\text { concrete }\end{array}$ & Fortaleza-CE (NE) & $\begin{array}{l}\text { ISO } 9001 \\
\text { LEED }\end{array}$ & Private & $\begin{array}{l}\text { Oct. } 2010 \text { to } \\
\text { Nov. } 2013\end{array}$ & $18,964,32.00$ & $2,855.88$ \\
\hline
\end{tabular}




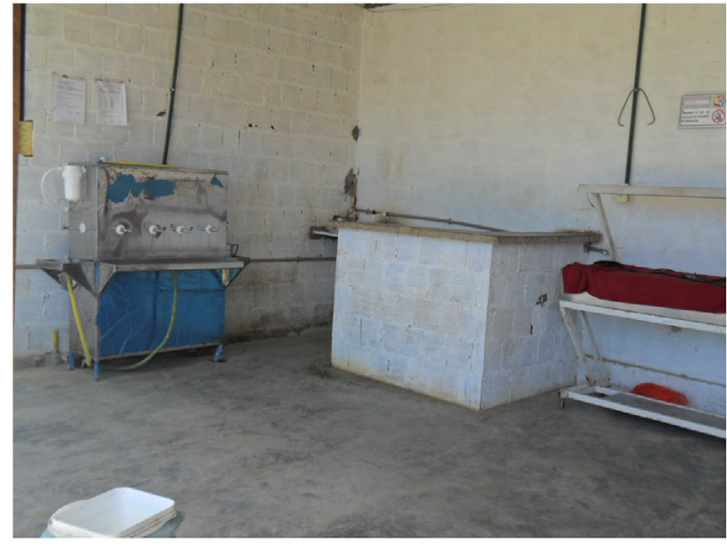

(a) Site $\mathrm{A}$

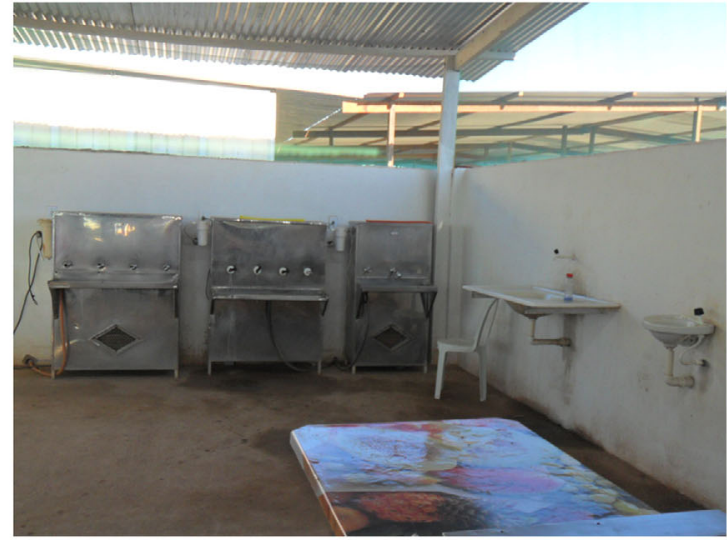

(b) Site

EXHIBIT 9 Best practices for supply of drinking water (a) site A and (b) site C [Color figure can be viewed at wileyonlinelibrary.com]

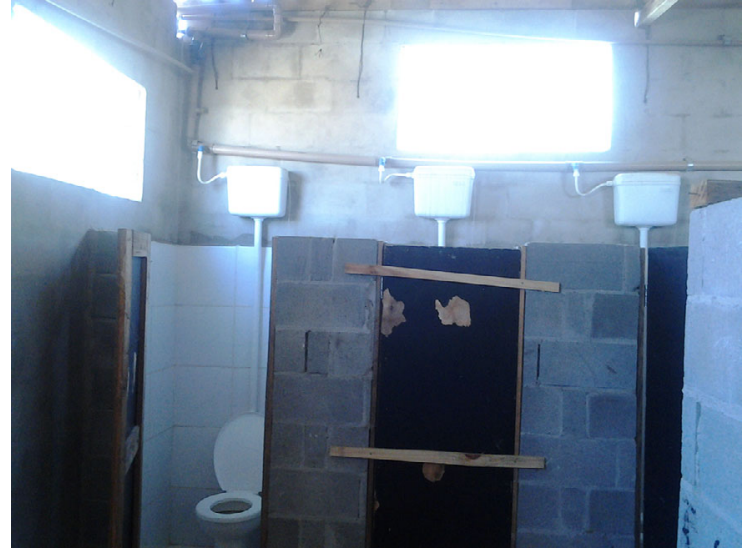

EXHIBIT 10 High-level flushing tank-site B [Color figure can be viewed at wileyonlinelibrary.com]

actions were observed with the investment in a system for capturing, storing, treating and reusing water. It was also considered an economic activity to obtain the HQE/AQUA or LEED sustainability seal at the construction sites B, E, and F. Only the bathrooms in the office facilities at construction site $\mathrm{E}$ had two toilet bowls with an attached box a and double flush mechanism, but that was not scored due to the small amount.

By completing the checklist according to Exhibit 6, one can evaluate each parameter on the list. For example, the subitem "2.3. Decrease of consumption" in Exhibit 6 has 3 questions with a maximum score of 12 points (corresponding to the maximum score 4 multiplied by 3 questions). The scores of the 3 questions shown can be observed in Exhibit 18, and are, respectively, 3, 4, and 1 for site A. The sum of the 3 questions is 8 points. Thus, the percentage score is obtained by multiplying the subitem score (12) by $100 \%$ and then dividing this number by the achievable score (8) to reach the rate of compliance of $67 \%$ in Exhibit 18. As a result, subitem "2.3. Decrease of consumption" shows a compliance rate or percentage of $67 \%$ for the observed practices for site A. Similarly, calculations are made for the other items on the list.

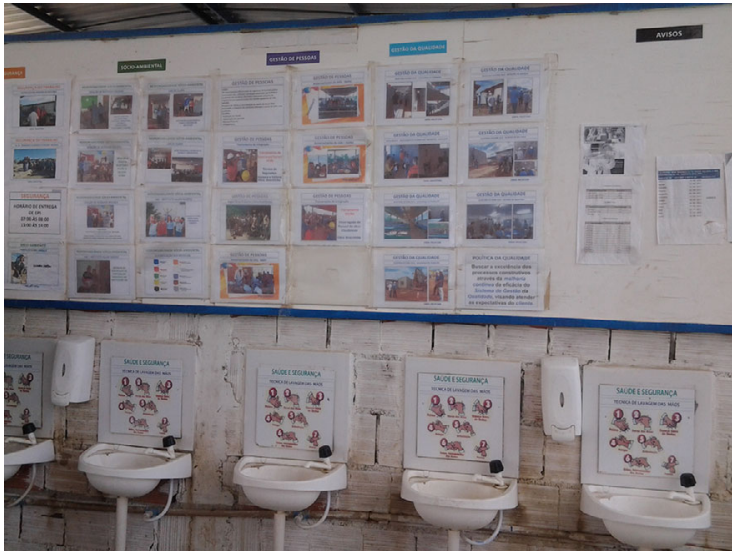

EXHIBIT 11 Instructions for workers to save water and health care-site $\mathrm{D}$ [Color figure can be viewed at wileyonlinelibrary.com]

The score of construction site $\mathrm{A}$ is $43 \%$, which will be the average of the 3 subitems observed. The percentage results obtained in each subitem for each construction site can be seen in Exhibit 19.

After the analysis of results, the final score for the "Rational use of water" item can be observed that the two constructions sites $A$ and $C$ obtained the worst scores. Site $A$ has the worst score, does not harvest graywater or rainwater, but has used consumption reduction strategies in the site. Site $C$ had a score of $47 \%$, and its better index was related to the use of technologies for wastewater. These two sites fit in level 1-construction with few sustainable practices, according to the classification proposed by Zeule (2014).

Rainwater harvesting is possible in several regions of Brazil, mainly in the southeastern (SE) region-sites B and $\mathrm{E}$. These were the two sites that scored in this item. However, in the northeastern (NE) region of Brazil, several locations collect rainwater for non-drinking purposes. It becomes necessary to disseminate this strategy more to construction companies.

Concerning sites B, D, and F with 56\%, 58\%, and 56\%, respectively, they would be framed in level 2 site with a good level of sustainable 


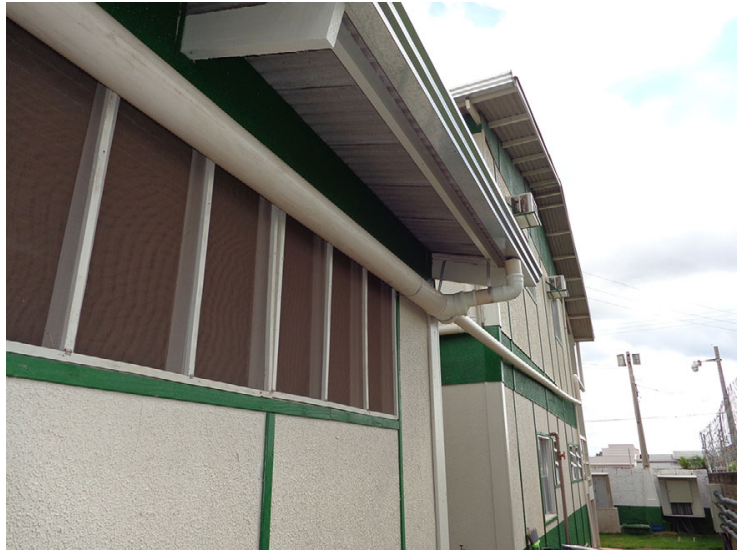

EXHIBIT 12 Rainwater harvesting by roof waterspouts-site E [Color figure can be viewed at wileyonlinelibrary.com]

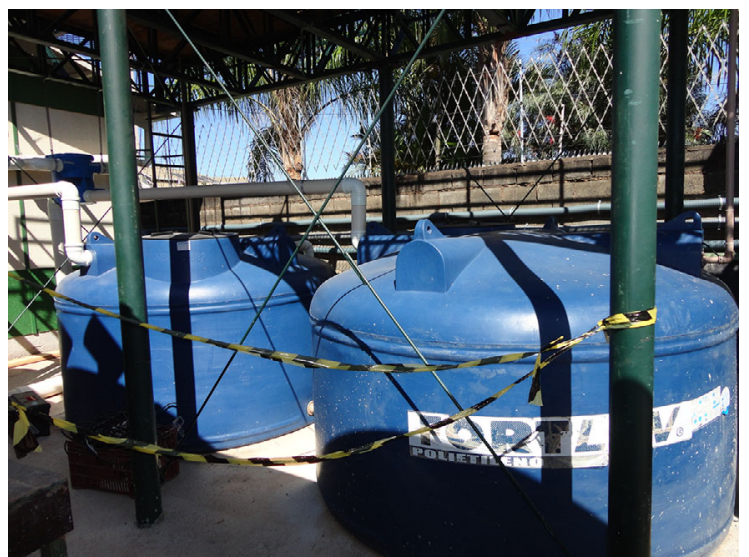

EX HIB IT 13 Tanks to reserve rainwater after treatment-site E [Color figure can be viewed at wileyonlinelibrary.com]

practices, and site $\mathrm{E}$, with the best score of the four plots with $81 \%$, would be at level 4 construction site with the excellent level of sustainable practices. Comparing them with Exhibit 8, we can see that $B$ and $E$ construction sites, which reached AQUA/HQE certification, achieved the highest scores according to the proposed instrument and present best practices of sustainability in water use. The AQUA/HQE certification has been well accepted in Brazil for presenting guidelines for implementing sustainability that is more appropriate to the country's reality.

Only site E carried out a quantitative study on water consumption in construction sites. The water consumption indicator predicted a volume of $17,395.00 \mathrm{~m}^{3}$, based on the number of months of execution (40 months) and the histogram (average of 148 employees per month), taking into account that each employee would consume on average the equivalent of $2.5 \mathrm{~m}^{3}$ per month. The actual consumption was $14,130.00 \mathrm{~m}^{3}$, according to the consumption history obtained by the accounts-saving of $18 \%$. During the measurement, it was found that the water consumption per built area was $0.29 \mathrm{~m}^{3}$ per $\mathrm{m}^{2}$. For those responsible, this high saving was a reflection of the measures implemented: recirculation of hot water in the water heating system

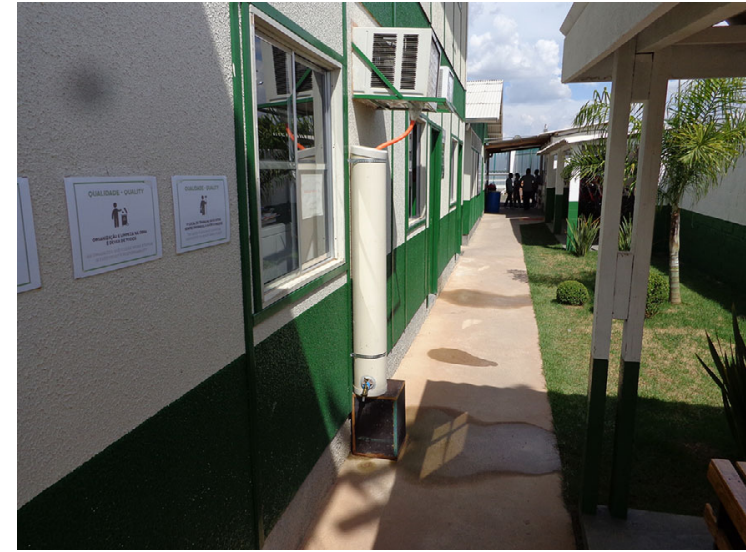

EXHIBIT 14 Collection of rainwater by the air-conditioning-site $\mathrm{E}$ [Color figure can be viewed at wileyonlinelibrary.com]

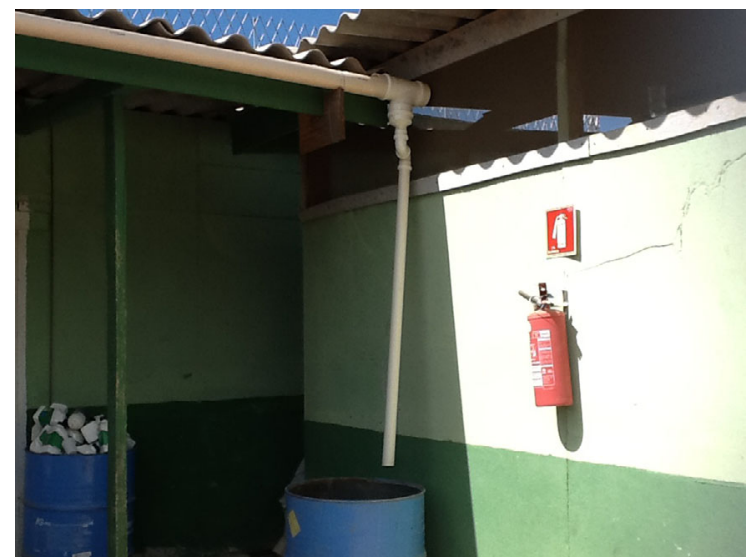

EXHIBIT 15 Collection of rainwater by the roof-site B [Color figure can be viewed at wileyonlinelibrary.com]

in the workers' locker room, flow restrictors in the taps, use of water of reuse from the washbasins and urinals, from the air devices conditioning, from rainwater, from the spout and wheel washer system, from the concrete mixer plant, and awareness actions and training of workers.

Thus, the following best practices applicable to the rational use of water can be proposed:

- Collection of rainwater and graywater (sinks and showers) and consequent treatment for reuse in construction site:

○ Capture rainwater and graywater;

Do the correct treatment of the water to be reused;

Observe if the captured water (rain and/or gray) was correctly treated afterward for reuse;

O Keep rainwater collection pipes and devices completely separate from drinking water facilities;

- Technologies used for wastewater: for separation and reuse purposes, wastewater is composed of black water (toilets and kitchen sinks) and graywater (showers, bathroom sinks, tanks): 


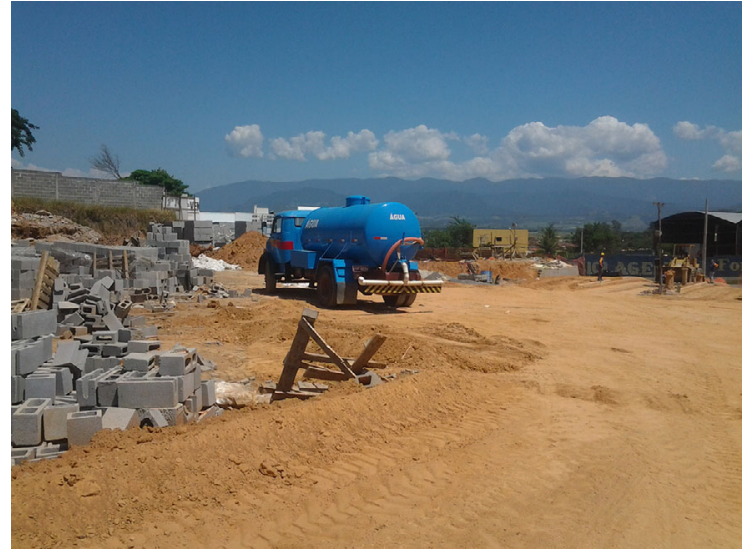

EXHIBIT 16 Water tanker vehicle to irrigate construction site-site B [Color figure can be viewed at wileyonlinelibrary.com]

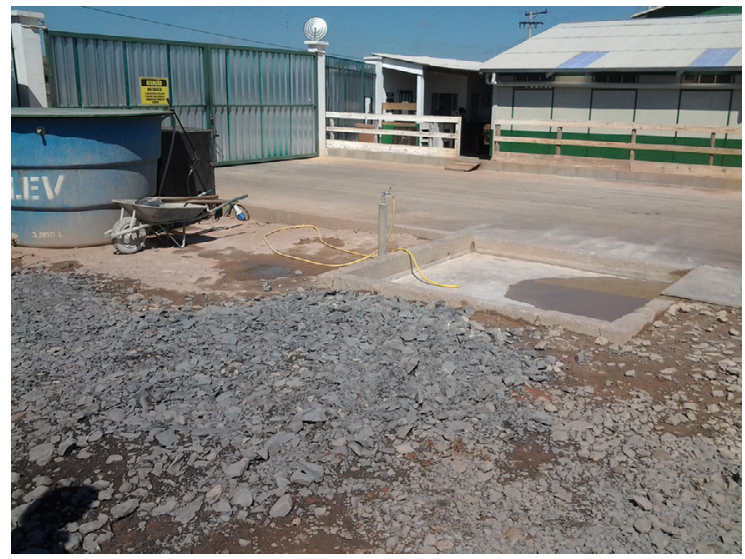

EXHIBIT 17 Place for washing vehicle wheels and concrete mixer truck with the metal hose-site $\mathrm{E}$ [Color figure can be viewed at wileyonlinelibrary.com]

Provide a system for draining black water from the site of construction;

Provide for the existence of a reservoir for settling waters with particulate material, such as hardened mortars, plaster and other residues that may interfere with the sewage collection system;

Establish periodic maintenance of wastewater installations;

- Reduction of water consumption: provide for the installation of devices and awareness strategies:

O Instruct workers often to save water through awareness courses or written guidelines;

Use water-reducing equipment in temporary installations, such as faucets with automatic closing, flushing box with a capacity of fewer than six liters, pressure reducer, and aerator.

\section{7 | CONCLUSIONS}

According to the results obtained, it is observed that the strategies for the use, reuse, and management of water at construction sites and sustainability practices were found in the six visited construction sites. Although the scores were low in both works, it is emphasized that there are initiatives to conserve water, which is an exhaustible natural resource and has been of great concern today. The best score was obtained by construction site $\mathrm{E}$, which has an environmental certification program and has minimum requirements that must be met since the execution phase.

The issue of sustainable construction certification seals is very recent in the country. Despite several studies on this subject, there is a lack of general indicators (benchmark) and calculation parameters for future applications. This is due both to the lack of certification that adapts to the needs of each location and to the lack of awareness of those involved.

It was found that the subitem "Rainwater and graywater" was little used mainly in public projects. It is believed that there should be initiatives by the contractor, in the case of governments, to recommend the use of this type of practice during execution phases.

Construction companies are recommended by legislation to seek an alternative that acts on reducing environmental impacts and adopt management tools such as the implementation of an environmental management system and a checklist as proposed by this study, which should be the solution for a company that wants to improve its position about the environment.

The purpose of the list is to show that the practices for the rational use of water can be applied on-site, even if there is no quantitative measurement of water consumption data. To measure water consumption and analyze savings, it is important to define methodologies for calculating the indicators. The benefits of best practices are consolidated by the methods applied to the four environmental certification seals that served as the basis for this proposal.

The relation of this theme-rational use of water in construction sites-with the current ongoing water crisis has social, economic, and environmental importance. Besides saving resources and preserving the environment, the adoption of sustainable practices improves the behavior of society, which must change its attitudes about everyday practices. In the context of this research, it was possible to notice that the harvesting and reuse of rainwater are sustainable practices that are viable and collaborative with society, in general.

Finally, we emphasize that tools such as the proposed checklist can serve as a resource for improving the implementation of sustainability in construction, especially in the construction site, which is the phase of greater movement and occurrences during the building process. They also bring social and economic benefits to the enterprise, besides the environment.

\section{ACKNOWLEDGMENTS}

For construction companies participating in the research. This study was financed in part by the Coordenação de Aperfeiçoamento de Pessoal de Nível Superior-Brasil (CAPES)-Finance Code 001 and Project 01.11.0056.00-FINEP (Financier of Studies and Projects)CANTECHIS-Technologies for Social Housing Scheme (HIS) Sustainable Construction Sites. 
EXHIB IT 18 Percentage of item/subitems and an average of the rational use of water

\begin{tabular}{|c|c|c|c|c|c|c|c|}
\hline 2. Rational use of water & Site $A$ & Site B & Site C & Site $\mathrm{D}$ & Site $\mathbf{E}$ & Site F & Average \\
\hline 2.1 Rain and graywater harvesting & $0 \%$ & $44 \%$ & $0 \%$ & $0 \%$ & $69 \%$ & $0 \%$ & $19 \%$ \\
\hline 2.1.1 Is there or will there be any rainwater collection system? & 0 & 2 & 0 & 0 & 3 & 0 & \\
\hline $\begin{array}{l}\text { 2.1.3 Is the collected water (rain and/or graywater) correctly } \\
\text { treated for reuse? }\end{array}$ & 0 & 1 & 0 & 0 & 4 & 0 & \\
\hline 2.2. Technologies for wastewater & $63 \%$ & $50 \%$ & $75 \%$ & $100 \%$ & $100 \%$ & $75 \%$ & $77 \%$ \\
\hline $\begin{array}{l}\text { 2.2.1 Was planned a discharge wastewater system during } \\
\text { building design? }\end{array}$ & 3 & 4 & 3 & 4 & 4 & 4 & \\
\hline 2.2.2 Are the wastewater facilities periodically checked? & 2 & 0 & 3 & 4 & 4 & 2 & \\
\hline 2.3.2 Are there any measures taken to fight the water waste? & 4 & 4 & 3 & 4 & 4 & 4 & \\
\hline Option ligation & A & A & B & B & A & A & \\
\hline Technological actions & $\mathrm{x}$ & $\mathrm{X}$ & $\mathrm{x}$ & $\mathrm{X}$ & $x$ & $x$ & \\
\hline Social actions & $x$ & $x$ & $x$ & $x$ & $x$ & $x$ & \\
\hline Economic actions & & $\mathrm{X}$ & & & $x$ & $x$ & \\
\hline $\begin{array}{l}\text { 2.3.3 Do the bathrooms have ceramics and metals which save } \\
\text { water? }\end{array}$ & 1 & 1 & 1 & 1 & 1 & 1 & \\
\hline Toilet bowl with coupled box & & & & & $x$ & & \\
\hline
\end{tabular}

\section{RATIONAL USE OF WATER}

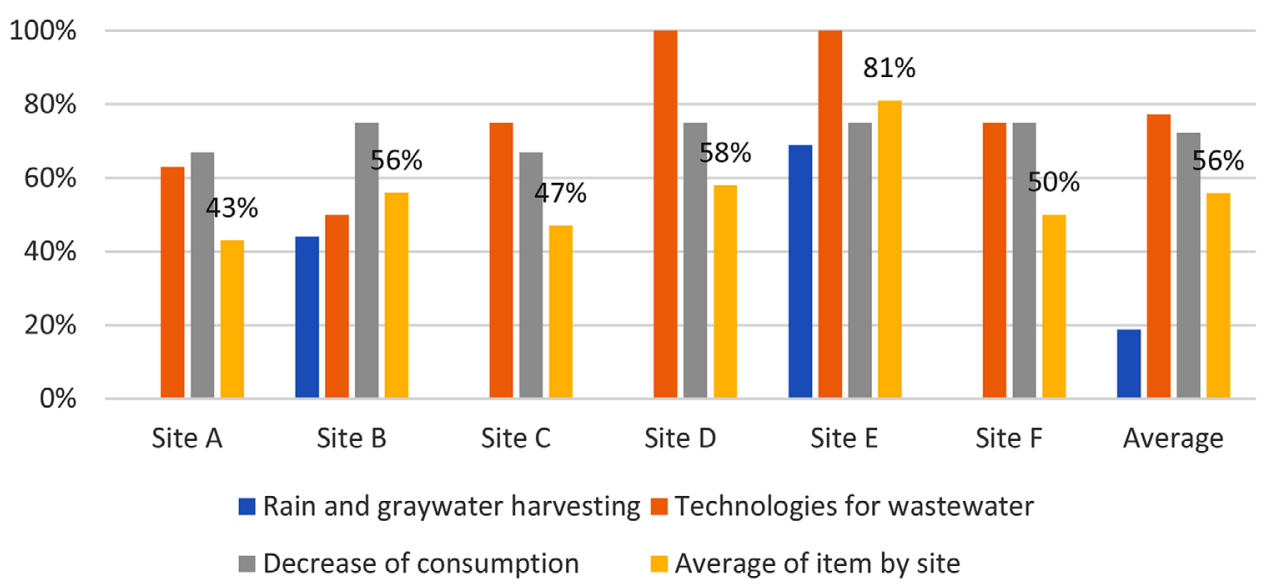

EXHIBIT 19 Percentage of item and average of the rational use of water in sites construction [Color figure can be viewed at wileyonlinelibrary.com] 


\section{ORCID}

Sheyla Mara Baptista Serra (DD https://orcid.org/0000-0002-9508-976X

\section{REFERENCES}

Ahn, Y., Shin, H., Jeon, M., \& Jung, C. (2017). Construction process framework for a green building projects. International Journal of Sustainable Building Technology and Urban Development, 8(4), 349-364. https://doi. org/10.22712/susb.20170032

Al-Qawasmi, J., Asif, M., El Fattah, A. A., \& Babsail, M. O. (2019). Water efficiency and management in sustainable building rating systems: Examining variation in criteria usage. Sustainability, 11, 2416. https://doi.org/10. 3390/su11082416

Borja, L. C. A., César, S. F., Cunha, R. D. A., \& Kiperstok, A. (2018). A quantitative method for prediction of environmental aspects in construction sites of residential buildings. Sustainability, 10, 1870. https://doi.org/10. 3390/su10061870

Brasil. (1997). Lei 9.433, de 08 de janeiro de 1997. Institui a Política Nacional de Recursos Hídricos. Diário Oficial da República Federativa do Brasil, Brasília, seção 1, p.470, v.135, n.6.

Ministério da Saúde, Brasil. (2011). Portaria 2914 de 12 de dezembro de 2011. Dispõe sobre os procedimentos de controle e de vigilância da qualidade da água para consumo humano e seu padrão de potabilidade. Retrieved from http://bvsms.saude.gov.br/bvs/saudelegis/gm/ 2011/prt2914_12_12 2011.html

Brasil. Ministério do Meio Ambiente. Conselho Nacional do Meio Ambiente (CONAMA). (2005). Resolução 357, de 17 de março de 2005. "Dispõe sobre a classificação dos corpos de água e diretrizes ambientais...". Retrieved from http://www.mma.gov.br/port/conama/res/ res05/res35705.pdf

Brasil. Ministério do Trabalho e Emprego. (2018). Norma Regulamentadora $\mathrm{n}^{\circ}$ 18: Condições e meio ambiente de trabalho na indústria da construção. Retrieved from https://enit.trabalho.gov.br/portal/images/ Arquivos_SST/SST_NR/NR-18.pdf

Brazilian Association of Technical Standards [Associação Brasileira de Normas Técnicas] (ABNT). (1997). NBR 13.969: Tanques sépticos: Unidades de tratamento complementar e disposição final dos efluentes líquidos: Projeto, construção e operação. 60p. Rio de Janeiro.

Brazilian Association of Technical Standards [Associação Brasileira de Normas Técnicas] (ABNT). (2007). NBR 15.527: Água de chuva: Aproveitamento de coberturas em áreas urbanas para fins não potáveis. 8 p. Rio de Janeiro.

Building Research Establishment (BRE). (2009). BREEAM Europe Commercial 2009 Assessor Manual. BRE Global Ltd 2009, 346p. Retrieved from https://tools.breeam.com/filelibrary/Technical\%20Manuals/ BREEAM_Europe_Commercial_2009.pdf

Castro, C. O., Loureiro, O. C. S., Santos, A. V., Silva, J., \& Rauen, W. B. (2017). Water sustainability assessment for the region of Curitiba. International Journal of Sustainable Building Technology and Urban Development, 8(2), 184-194. https://doi.org/10.12972/susb.20170016

Environmental Protection Agency (EPA). (2012). Guidelines for water reuse. Washington. Retrieved from https://www.epa.gov/sites/production/ files/2019-08/documents/2012-guidelines-water-reuse.pdf

Federal Savings Bank [Caixa Econômica Federal] (CEF). (2010). Blue house seal-Good practices for more sustainable housing [Selo Casa Azul - boas práticas para habitação mais sustentável]. Vanderley M. John \& Racine T.A. Prado. São Paulo, Brazil: Pages \& Lyrics Publisher and Graphics [Páginas \& Letras Editora e Gráfica]. Retrieved from http://www.caixa.gov.br/ Downloads/selo_casa_azul/Selo_Casa_Azul.pdf

Foundation Carlos Alberto Vanzolini [Fundação Carlos Alberto Vanzolini] (FCAV). (2013). Certification technical reference: Residential buildings-AQUA process [Referencial técnico de certificação: Edifícios habitacionais-processo AQUA]. Alto da Lapa; Author. Retrieved from https://www.vanzolini.org.br/download/ RT_Edificios_habitacionais_v2_2013.pdf
Giacchini, M. (2016). Uso e Reúso da Água. Technical Series Reports. Regional Council of Engineering of the State of Paraná (CREAPR), Brazil. Retrieved from https://www.crea-pr.org.br/ws/wp-content/ uploads/2016/12/uso-e-reuso-da-agua.pdf

Halliday, S. (2010). Sustainable construction. Burlington: ButterworthHeinemann.

Queensland Government. Department of Employment and Industrial Relations. (2007). Model water management plan for the queensland civil construction industry. $17 \mathrm{p}$. Retrieved from https://www.dnrme.qld.gov. au/_data/assets/pdf_file/0019/45172/water-quality-guidelines.pdf

Reis, R. P. A., Souza, U. E. L., \& Oliveira, L. H. (2004). Alternativas e Soluções de Instalações Hidráulicas Provisórias em Canteiros de Obras. 10p. In: I Conferência Latino-Americana de Construção Sustentável (CLACS). Proceedings...São Paulo.

Santos, C., Taveira-Pinto, F., Cheng, C. Y., \& Leite, D. (2011). Development of an experimental system for greywater reuse. Portugal: Faculty of Engineering, University of Porto. https://doi.org/10.1016/j.desal.2011.10.017

Santos, C. P., Silva, S. R., \& Cerqueira, C. A. (2015). Water consumption in construction sites in the city of Recife/PE. Electronic Journal of Geotechnical Engineering (EJGE), 20, bundle 7, 1711-1725. Retrieved from http: //www.ejge.com/2015/Ppr2015.0243ma.pdf

São Paulo State Environmental Company [Companhia Ambiental do Estado de São Paulo] (CETESB). (2020). Reúso de água. Retrieved from https://cetesb.sp.gov.br/aguas-interiores/informacoes-basicas/tposde-agua/reuso-de-agua/

Thomson, C., \& El-Haram, M. (2014). Potential and implications of sustainability action plans: Lessons from the Greater Middlehaven Regeneration Project. Built Environment Project and Asset Management, 4(1), 108122. https://doi.org/10.1108/BEPAM-11-2012-0053

Thornback, J., Snowdon, C., Anderson, J., \& Foster, C. (2015). Water efficiency: The contribution of construction products.London: Construction Products Association, 40p. Retrieved from https://www. constructionproducts.org.uk/media/87904/water_efficiency_report. pdf

UNESCO World Water Assessment Programme. (2020). The United Nations world water development report 2020: Water and climate change. 219p. Retrieved from https://unesdoc.unesco.org/ark:/48223/ pf0000372985.locale=en

United States Green Building Council (USGBC). (2019). US Green Building Council announces top 10 countries and regions for LEED Green Building. Retrieved from https://www.usgbc.org/articles/us-green-buildingcouncil-announces-top-10-countries-and-regions-leed-green-building

United States Green Building Council. (2009). Leadership in energy and environmental design-LEED for new construction and major renovation, version 2.2, reference guide (2nd ed.). Retrieved from https://www. usgbc.org/resources/leed-new-construction-v2009-current-version

Usman, A. M., \& Abdullah, K. (2018). Water management and efficiency for construction industries in green building rating systems. On: 4th Putrajaya International Built Environment, Technology and Engineering Conference (PIBEC4), Bangi, Malaysia, pp. 573584. Retrieved from https://www.researchgate.net/publication/ 324111287_Water_Management_and_Efficiency_for_Construction_ Industries_in_Green_Building_Rating_Systems

Waidyasekara, K. G. A.S., De Silva, M. L.D., \& Raufdeen, R. (2013). Value of sustainable use of water in construction industry. In 12th Sustainable Built Environment (SBE). Retrieved from http://dl.lib.mrt.ac.lk/handle/ $123 / 9032$

Waylen, C., \& Williams, H. (2011). Water: A progress report on reducing water use on construction sites. Report 12. London: Construction Products Association, 17p. Retrieved from https://waterwise.org.uk/wpcontent/uploads/2019/09/WRAP-2008_Water_A-Progress-Reporton-Reducing-Water-Use-on-Construction-Sites.pdf

Yin, R. K. (2013). Case study research: Design and methods (5th ed.). Newbury Park, CA: Sage. 
Zeule, L. O. (2014). Sustainability practices and assessment on construction sites. (Práticas e avaliação da sustentabilidade nos canteiros de obras.) Master's Dissertation in Structures and Civil ConstructionFederal University of São Carlos, São Carlos, 263f. Retrieved from https: //repositorio.ufscar.br/handle/ufscar/4704

Zeule, L. O., Serra, S. M. B., \& Teixeira, J. M. C. (2019). Model for sustainability implementation and measurement in construction sites. Environmental Quality Management, 29(2), 67-75. https://doi.org/10.1002/tqem.21666

Zutshi, A., \& Creed, A. (2015). An international review of environmental initiatives in the construction sector. Journal of Cleaner Production, 98, 92106. https://doi.org/10.1016/j.jclepro.2014.06.077

\section{AUTHOR BIOGRAPHIES}

Ludimilla de Oliveira Zeule graduated in Technology in Civil Construction (2011) from the State University of Maringá. She has a PhD in Civil Construction (2018) in Civil Engineering Postgraduate Program (PPGECiv) at the Federal University of São Carlos (UFSCar), Brazil. Her main research areas include sustainability in construction, decision-making method, selection of low-impact materials, application of sustainability checklist, management and planning of the construction site.

Sheyla Mara Baptista Serra is a civil engineer from the Federal University of Juiz de Fora (UFJF) and Doctor in Civil Engineering at the University of São Paulo (USP), Brazil. She is associate professor at the Civil Engineering Department of the Federal University of São Carlos (UFSCar), since 1994. Her main research areas include construction management, planning and scheduling, subcontractor management, construction site, lean construction, sustainable construction, Building Information Modeling (BIM), and safety and health at work.

José Manuel Cardoso Teixeira graduated in Civil Engineering from the Faculty of Engineering of the University of Porto (FEUP), Portugal, and obtained the degree of Doctor of Civil Engineering from the Loughborough University Faculty of Engineering, UK. He has been an associate professor at the Department of Civil Engineering since 1994 and a researcher at the Center for Territory Environment and Construction (CTAC) in the field of sustainable construction.

How to cite this article: Zeule LdO, Serra SMB, Teixeira JMC. Best practices for the rational use of water in construction sites in Brazil. Environ Qual Manage 2020;29:73-85.

https://doi.org/10.1002/tqem.21693 